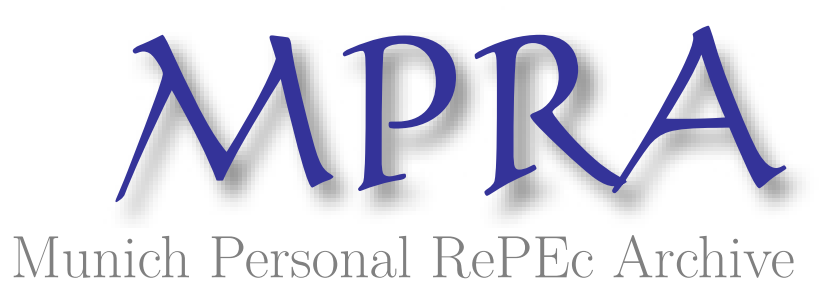

\title{
Political budget cycles and social security budget increases in the Republic of Ireland, 1923-2005
}

Cousins, Mel

Glasgow Caledonian University

26 June 2007

Online at https://mpra.ub.uni-muenchen.de/5359/

MPRA Paper No. 5359, posted 18 Oct 2007 UTC 


\section{Political budget cycles and social security budget increases in the Republic}

of Ireland, 1923-2005

Abstract: This working paper examines social security increases in Ireland as a case study of the existence of political budget cycles in European countries. Ireland is an appropriate country to examine, first because it has a system of proportional representation and some studies suggest that proportional electoral systems are associated with expansions of welfare spending both before and after elections. Second, it is generally recognised that Irish political parties occupy the middle ground in terms of political ideology. Again studies would suggest that an absence of a strong ideological commitment to particular policies may make political budget cycles more likely. Utilising the distinctive nature of the public expenditure process in relation to welfare budget increases, this paper examines the issue of whether or not a political budget cycle can be seen in Ireland in relation to social security expenditure. It draws a number of conclusions as to the existence and incidence of political budget cycles in an Irish context and also looks at whether political budget cycles have succeeded in their apparent objective i.e. securing election for the relevant political party. 
There has been considerable academic debate and research about the existence of political budget cycles. A political budget cycle can be defined as 'a periodic fluctuation in the government's fiscal policies, which is induced by the cyclicality of elections' (Shi and Svensson, 2003). Much of the research has focused on quantitative studies of a relatively large number of countries. While there have been a number of more specific studies particularly in Latin America, there are relatively few studies in an European context and, in particular, few national studies. This paper takes the case of social security spending in the Republic of Ireland (hereafter Ireland) as a case study in relation to the existence of political budget cycles in developed countries. Ireland is an appropriate country to examine, first because it has a system of proportional representation and some studies suggest that proportional electoral systems are associated with expansions of welfare spending both before and after elections (Persson and Tabellini, 2002). Second, it is generally recognised that Irish political parties occupy the middle ground in terms of political ideology. Again studies would suggest that an absence of a strong ideological commitment to particular policies may make political budget cycles more likely (Persson and Tabellini, 1990). This paper examines the issue of whether or not a political budget cycle can be seen in Ireland in relation to social security budget increases.

The first section of this paper reviews the extensive literature in this area. The second section outlines the methodology and approach to this study of the social security (or social welfare as it is known) budget increases in Ireland. The subsequent section 
presents and analyses the evidence while the final section 4 concludes and summarises the findings.

\section{Literature review}

The literature on political budget cycles is an offshoot of the broader debate about the existence of a political business cycle. This studies the effect of politics and in particular elections, on the economy looking, for example, at their impact on GDP growth and unemployment (Shi and Svensson, 2003). In general, the notion that a country's economic performance could be influenced by political cycles received little academic support not least because of the limited ability of politicians to manipulate the economy (Remmer, 1993; Drazen, 2001; Shi and Svensson, 2003). Accordingly, research has tended to focus more narrowly on political budget cycles looking at those policy instruments directly within the control of government (such as fiscal policy and government spending). The basic rationale behind the political budget cycle literature is that governments will manipulate fiscal and expenditure policy, in part, in order to obtain electoral success.

There are a number of competing theories as to why such manipulation might be acceptable to voters-some of them relying on the assumption that voters are non-rational. One of the more credible rationales has been put forward by a Persson and Tabellini (1990). They argue that governments are primarily interested in securing re-election rather than in implementing ideological policies. They also assume that voters are rational but are unaware of the 'competence' of the political contenders (where 
competence is defined as efficiency in the provision of public services). Given that voters prefer competent governments, rational voters will interpret a pre-electoral spending boom as a device signalling competence. However, as Kraemer (1997) points out, while this model can serve as a useful starting point, the distinction between competent and incompetent governments is much more blurred in the real world. Voters will find it difficult to distinguish between competent and incompetent governments and an incompetent government will, of course, tend to mimic the behaviour of a competent one and expand spending where elections are expected. This highlights the point that it is not simply the policy measures adopted by a government which are important. Rather voters will also take into account the 'political capital' of the government, the manner in which its proposals are presented and the credibility of the criticisms and alternative proposals advanced by the opposition. ${ }^{1}$ As will be discussed in more detail below, social security spending is particularly relevant in this context as it is arguably a clear manner in which a governing party can show its 'competence'.

A number of studies have indeed found evidence of political budget cycles. Alesina, Cohen and Roubini (1991), looking at a sample of 18 OECD countries, found evidence of expansionary monetary policy in election years and also indications of loose fiscal policy prior to elections. In a study of 60 democratic countries in the period from 1960-1998, Persson and Tabellini (2002) found that taxes were cut before elections and painful fiscal adjustments were postponed until after elections (although they found no evidence of a

\footnotetext{
${ }^{1}$ This process was well illustrated in the run-up to the Irish 2002 and 2007 general elections (Gallagher et al., 2003)). In earlier work Harrison and Marsh (1998) found that economic performance set the general level of government approval but did not affect more short-term fluctuations.
} 
welfare state spending cycle). ${ }^{2}$ Of particular interest in an Irish context, Persson and Tabellini (2002) found that majoritarian electoral rules were associated with pre-electoral spending cuts while proportional electoral systems were associated with expansions of welfare spending both before and after elections. However, Brender and Drazen (2004) found both that political budget cycles generally and the relationship with proportional representation was confined to newly established democracies.

A number of recent econometric studies have examined whether political budget cycles can be seen in EU countries but have come to conflicting conclusions. Focusing on taxes and expenditure, Andrikopoulos et al (2004) found no evidence that national governments of the member states of the EU manipulated the fiscal policy instruments at their disposal for electoral purposes. In contrast, focusing on the general government balance, Tujula and Wolswijk (2004) found that fiscal balances on average deteriorated by about $0.4 \%$ of GDP in general election years (controlling for other factors). Warin and Donahue (2006) - who examined the fiscal balance, government revenue and expenditure - also found evidence of a political budget cycle in the period 1979-2005 but argue that the Treaty of Maastricht and the constraints imposed by the Stability and Growth Pact have more recently constrained governments from adopting a political budget cycle. Von Hagen (2003), Buti and van den Noord (2003) and Mink and de Haan (2005) also found evidence in support of political budget cycles in the EU but these latter studies were confined to a period of only four or five years.

\footnotetext{
${ }^{2}$ See also Drazen (2001); Shi and Svensson (2002a and b; 2003)
} 
Political budget cycles have also been found in a number of detailed studies in less developed countries such as Argentina, ${ }^{3}$ Brazil, ${ }^{4}$ Colombia, ${ }^{5}$ Mexico, ${ }^{6}$ Peru, ${ }^{7}$ Venezuela, ${ }^{8}$ Korea ${ }^{9}$ and Turkey. ${ }^{10}$ However there have been relatively few country studies in Europe. Van Dalen and Swank (1995) examined whether opportunistic motives affected government expenditure growth in the Netherlands. ${ }^{11}$ Looking at the period from 19531993, the authors found that, in general, government spending was affected by opportunistic motives. In particular, they found that all government expenditure categories showed an upwards trend during election times. ${ }^{12}$ There do not appear to be any published studies of political budget cycles in Ireland in terms of government spending although there are frequent references in the political science literature to high levels of clientelism and (somewhat undefined) populism which would suggest that it is an appropriate country for study. ${ }^{13}$

\section{Methodology of the study}

\footnotetext{
${ }^{3}$ Medina and Lema (2003). For a review of Latin America generally see Kraemer (1997).

${ }^{4}$ Bittencourt and Hilbrecht (2002).

${ }^{5}$ Eslava (2005).

${ }^{6}$ Bruhn (1996); Dion (2000); Gonzalez (2002); Yarahuan (2003); Magaloni et al.(2003).

${ }^{7}$ Schady (2000).

${ }^{8}$ Puente (2004).

${ }^{9}$ Kwon (2001). It is interesting to note that this study of a developmental state found strong evidence that the timing and distribution of public expenditure could be explained by the logic of electoral politics.

${ }^{10}$ Tutar and Tansel (2000); Asutay (2004).

${ }^{11}$ See also Akmedov and Zhuravskaya's (2004) study of political cycles in Russia and Galli and Rossi's (2002) study of cycles in German lander.

${ }^{12}$ The study also examined the effect of party politics but this aspect is flawed by the fact that it looks only at the impact of left (PvDA) and right wing (VVD) parties and effectively assumes that the Christian Democratic party (CDA) had no influence: a strange assumption when the CDA has been the largest party of government throughout the 20th century and one of the main founders of the Dutch welfare state. ${ }^{13}$ Amongst the numerous such references see Carty (1984), Komito (1984) and O'Malley and Kerby (2004).
} 
As we have seen, most of the studies of political budget cycles involve a large number of countries and rely on quantitative methodologies. There are advantages and disadvantages to this approach. Larger scale quantitative studies can allow a wide range of factors to be taken into account over a considerable period of time in a large number of countries. Such quantitative studies use sophisticated econometric methods to analyse the relationship between factors such as the level of economic development or the strength of particular political parties and the existence of a political budget cycle (variously measured). Unfortunately, however, the availability of data and the linking of the data to the theory do not always match the sophistication of the econometric methods used and there have been a number of recent important criticisms of aspects of quantitative approaches (Shalev, 2002, Hall, 2003; Ebbinghaus, 2003). In addition, as we have seen in the case of recent European studies, where research projects come to different conclusions as to the existence or otherwise of political budget cycles, it is difficult to penetrate the 'black box' of the methodology to discover which finding is 'correct'.

Hall (2003, 373-4) argues that a substantial gap has opened up between ontology (in the sense of 'the fundamental assumptions that scholars make about the nature of the social and political world and especially about the nature of the causal relationships within that world) and methodology ('the means scholars use for ensuring that their inferences about the social political world are valid'). Most ontologies now assume that policy outcomes are the result of complex interaction effects and various forms of multiple causality whereas many statistical methods are based on much more restrictive assumptions about 
causal relationships (e.g. independence of variables, steady impact over time and space, absence of multiple causality). This is not to deny the value of statistical methods. However, it is to insist on the importance of inspecting not only the correspondence between the data representing 'causes' and those representing 'outcomes' but also the process whereby those causal factors operate so as to lead to those outcomes (Hall, 2003). As Hall (2003) argues the essence of explanation does not simply lie in specifying a set of 'explanatory variables', particular levels of which can be said to correlate with an outcome, but in explaining the mechanisms whereby one factor leads to another. This study adopts an alternative, more qualitative, approach looking in detail at one particular country.

Many studies use total government expenditure as the dependent variable when examining the existence of a political budget cycle. This approach suffers from the disadvantage that many aspects of government spending may not be particularly effective (or may even be counter effective) in terms of the supposed aims of the political budget cycle. One might expect, therefore, that a political budget cycle would lead to changes in the composition of rather than (or as well as) the size of the budget (see, for example, Eslava, 2005). Perhaps for these reasons, other studies confine themselves to an examination of welfare state spending. This still suffers from the disadvantage, which also applies to the study of overall government expenditure, that changes in spending are affected by a wide range of factors other than government policy. The ageing of the population, for example, in the absence of any change in public policy, will lead to increased spending on the old-age pensions. Similarly, a rise in unemployment will, 
absent policy change, lead to an increase in spending on unemployment. Thus, in using total expenditure (either overall government expenditure or total welfare state expenditure) it is necessary to control for such factors. This is not unproblematic and gives rise to questions as to whether the ultimate findings of such studies are correct or simply the result of inadequately controlling for other factors.

In this study we will look at increases in social welfare expenditure. ${ }^{14} \mathrm{~A}$ focus on social security expenditure appears particularly appropriate in examining whether or not political budget cycles exist. Social security expenditure constitutes a significant proportion of total government expenditure in Ireland (over 25 per cent. of current expenditure). In addition, the vast bulk of the expenditure goes directly to a large number of voters rather than being absorbed in administration costs. Thirdly, improvements in the social security area are quickly apparent without the lead time often necessary in other policy areas such as health or education.

In the Irish context, the particular structure of the Irish budgetary process provides an alternative source of data which helps to avoid issues of controlling for non-policy related changes in government spending. For largely historical reasons, increases in social security spending in Ireland normally involve a two-stage process. First, some weeks before the budget, increases due to demographic and labour market changes are announced in the Estimates. These aim to provide the necessary resources to fund the existing level of benefits in the following financial year on what has become known as a

\footnotetext{
${ }^{14}$ In the Irish context, social welfare expenditure includes all classic social security schemes such as unemployment, disability, old age and family benefits but does not include health services. I use the terms 'social security' and 'social welfare' interchangeably in this paper.
} 
'no policy change' basis, i.e. having regard to likely changes in the number of claimants but making no allowance for increases in benefit rates, improvements in schemes nor the introduction of new benefits. In contrast, in the area of other social services such as health and education, the Estimates normally make provision for improvement in services in the coming year. ${ }^{15}$ Second, on Budget day, the Minister for Finance announces what has become known as the 'social welfare budget package', i.e. a specific amount of money provided for increases in rates, improvements in existing schemes, or the introduction of new schemes. This is now a longstanding practice. It first appears -in an Irish context- in the first Fianna Fáil budget of 1932 albeit that there is an element of inconsistency in following decades as to whether funding will appear in the Estimates or in the Budget. ${ }^{16}$ However, since 1960 there has been a consistent pattern of announcing a sum in the budget for social security improvements (known hereafter as the social welfare budget package although the term itself appears to be of more recent origin).

Given the basic objective underlined the political budget cycle approach, i.e. to encourage voters to vote for the relevant political party, the social welfare budget package appears a very useful indicator of whether or not a political budget cycle exists. The general assumption is that-in most political contexts-governments will receive little credit for simply ensuring that existing (or future) claimants receive the benefits already provided for them. Rather-at least in an Irish context-there is a longstanding expectation

\footnotetext{
${ }^{15}$ Of course, in some cases, the Estimates may also provide for reductions (cutbacks) in certain services as in the 2004 social welfare estimates. This, however, is the exception rather than the rule and such reductions tend to be of a relatively minor nature in the context of the overall estimates. There are a number of exceptions to this when cutbacks were quite significant such as in 1987.

${ }^{16}$ For example, funding for the introduction of unemployment assistance in 1934 was provided in the Estimates rather than in the Budget.
} 
amongst voters that governments will attempt to ensure that benefits are 'improved' or at the very least that they do not disimprove in real terms. A focus on the social welfare budget package allows this aspect of government policy to be analysed disregarding 'existing commitments' without having to introduce complex methods of statistical control.

The social welfare budget package is, of course, not a perfect measure. First, the social welfare budget package only relates to the cost of improvements in the current financial year and in the following full financial year. ${ }^{17}$ The longer-term impact of significant increases is subsumed into the Estimates after the first year. In addition, there are issues of the data comparability over the long-term examined in this study. While, in recent years, data are available for both the current and full year costs, in many cases only the current year cost is given in earlier budgets. ${ }^{18}$ For this reason the analysis in the following section focuses primarily on periods for which comparable data are available rather than trying to make a comparison over the entire period. Third, one cannot simply compare the size of the social welfare budget package for example 1933 with that in say 2003.

\footnotetext{
${ }^{17}$ The "current year" cost relates to the cost of the measure in the current financial year. The "full-year" cost relates to the cost in a full financial year. Insofar as a budget measure is implemented from the start of the financial year, the two costs would be the same. However, it is often the case for financial or administrative reasons that a new policy measure is implemented during the financial year and the cost in the current year is therefore less than it would be in a full financial year. The full year cost is obviously the more reliable measure and is used wherever possible in this study. However, it is unfortunately the case that, particularly in the earlier period, the cost is often only provided on the current year basis. There is, however, a high degree of correlation be two series which indicates that, overall, the current year data does provide a reliable indicator of budgetary trends.

${ }^{18}$ There are almost certainly other definitional changes in how the social welfare budget package is costed over time. Unfortunately the detailed method of calculation is rarely available for earlier years.
} 
While there are a variety of ways of controlling for the fact that the value of money changes over time, in this analysis we present data in relation to the budget package as a percentage of national income, where this is available (see appendix 1). ${ }^{19}$

\section{Identifying a political budget cycle}

How might we identify a political budget cycle? Firstly, over the period for which consistent budgetary increases have been provided and for which comparable data are available (1960-2005) we look at the size of the social welfare budget package as a percentage of gross national/domestic product in pre-election budgets (i.e. the one or two budgets before an election), post-election budgets (the budget after an election) and nonelection budgets. Secondly, given that we might expect that the existence of political budget cycles will vary over time and because some data are only comparable within specific time periods, we analyse in a more qualitative manner social welfare budget packages over specific periods. Intuitively we might expect that the ruling party would provide increased social welfare budget packages in the one or two budgets before an election, while an opposition party (which obviously can't do this) would promise increased benefits in the election campaign and deliver these in the one or two budgets after the election (thereafter itself following the pattern of a ruling party). In this study we look at whether pre-or post budgets (shown as a percentage of national) are significantly higher than the preceding or following budgets. ${ }^{20}$ The findings are discussed in more detail in the following section. ${ }^{21}$

\footnotetext{
${ }^{19}$ Although not included in appendix 1, the analysis also looked at increases in the cost of living in the relevant periods.

${ }^{20}$ For the purposes of this analysis, we define the pre-election budget normally as the budget immediately before the election. Post-election budgets are taken to be the budget immediately after an election. While a
} 


\section{Findings of the study}

The trends in relation to social welfare budget packages are set out in appendix 1 and shown graphically in figures 1-4 (for the period from 1960). ${ }^{22}$ As can be seen there is no general unilinear trend in relation to the size of social security increases. Large increases began with the advent of Fianna Fáil governments in the early 1930s (reaching 1 per cent. of national income in 1934 with the introduction of unemployment assistance) but, subsequently, increases in the period to the 1960s tended to be quite small (with the exception of specific years such as 1944 (introduction of child benefit) and 1952 (unified social security scheme)). The size of increases rose somewhat from the mid 1960s and then rose dramatically during the early years of the Fine Gael-Labour coalition (197377). Budget sizes peaked again in 1980-1 before falling back to more modest levels (not much more than $0.5 \%$ of GNP on a full year basis) until a recent peak (about $1 \%$ in full year terms) before the 2002 and 2007 elections.

But can evidence of any political budget cycle be seen in relation to social security expenditure increases? We look firstly at the overall position in the period from 1960 when consistent and comparable data are available.

case could be made for examining the two budgets before and after an election, in the Irish case this would result in almost no nonelection budgets. In a small number of cases where the parliamentary term ran for five years, we include two pre-election projects.

${ }^{21}$ A more detailed discussion of the methodology is found in appendix 1.

${ }^{22}$ The data (outlined in Appendix 1) is taken from the budget speeches of successive Ministers for Finance which are published in the Dáil debates and as separate booklets from 1958. Data for the period 1991-2007 was kindly provided by the Department of Social and Family Affairs. 
Insert table 1

As can be seen, overall pre -election budgets do tend to be considerably larger and postelections budgets somewhat larger than in non-election years. However, there is very substantial year-on-year variation in budget sizes and the removal of the pre-election budgets in 1980 and 1981 would entirely remove the pre-election year advantage (as would the removal of the record 1973 budget affect the post-election advantage). Accordingly, it is necessary to look in more detail at the individual time periods.

$1922-57$

Following a period of rebellion, Ireland became independent of the United Kingdom in 1922. This was immediately followed by a split in the Sinn Féin party which led to the establishment of two main parties: Cumann na nGaedheal (later Fine Gael) and Fianna Fáil. In the initial period from 1923 to 1932, with the fiscally conservative Cumann na nGaedheal in power, there is no evidence of any political budget cycle. This is unsurprising given that the government of the period did not generally seek support through social policy expenditure and, in fact, became infamous for its reduction in old age pension rates. ${ }^{23}$

In 1932 a more radical Fianna Fáil assumed office, initially with the support of the Labour party. However, the initial period of Fianna Fáil rule over 16 consecutive years from 1932 to 1948 also does not show any sustained signs of political budget cycles. The coming to power of Fianna Fáil in 1932 certainly led to a significant increase in social

\footnotetext{
${ }^{23}$ See, for example, Cousins (2003).
} 
expenditure but this, in fact, took place mainly in the years immediately following the 1932 and the surprise 1933 election and spending dropped significantly coming up to the 1937 and 1938 elections (appendix 1). Nor is there any sign of a political budget cycle in relation to the 1943 election-a finding supported by a broader analysis of the politics of that election (Lee, 1985). However, there are indications that Fianna Fáil put much more emphasis on social policy measures in the 1944 election, in particular, the introduction of the children's allowance scheme and spending of over $£ 2$ million pounds was provided for the introduction of that scheme in a full year. However, despite significant increases in overall expenditure in the post-war years, there is in no sign of a political budget cycle in the subsequent 1948 election.

The 1948-57 period was one of political instability. An Inter-party government replaced Fianna Fáil in office in 1948 and itself fell following internal dissension in 1951. Fianna Fáil returned to office until 1954 when it was replaced by the second Inter-party government. There is little indication of a political budget cycle in this period. Spending increases in the social security area were quite modest and in many years no specific additional provision was made for improvements in benefits. The major improvement in this period was the introduction of a comprehensive social security scheme eventually introduced by Fianna Fáil in 1952-3. Significant spending increases were provided for this, firstly by the Inter-party government in 1951 and, secondly, by Fianna Fáil in 1952. However, while party political factors clearly played a role in the introduction of this scheme, the specific timing of its introduction does not appear to be related to a political budget cycle. Indeed, although it marked a significant increase in welfare spending, the 
1952 budget was widely seen as extremely harsh and included the scrapping of food subsidies (albeit with the provision of some additional compensation through the social security system) (see Bew and Patterson,1982, 65).

$1957-72$

This period covers the second era of Fianna Fáil hegemony. This is the first period for which increases are a consistently provided on an annual basis (from 1960). As set out in table 1, expenditure increases provided, while quite modest compared to the 1930s or later periods, were significantly higher in the pre and post-election budgets than in nonelection years. However, any significant political budget cycle effect in this period appears to be confined to the 1969 and 1973 elections. ${ }^{24}$ And even here the very modest nature of the effect - compared to the post-1973 increases - must be emphasised.

Insert figure 1

$1973-86$

This was a second period of political instability. A coalition government of Fine Gael and Labour took office in 1973 but was replaced by Fianna Fáil in the 1977. In 1981 and 1982 there were no less than three elections. In June 1981, a coalition government of Fine Gael and Labour was narrowly elected to office but resigned following the failure to achieve support for its budget in January 1982. Fianna Fáil resumed office after elections in February 1982 but this government fell later that year and a Fine Gael-Labour coalition

\footnotetext{
${ }^{24}$ The budget following the 1965 election was also well above average but the pre-election budget was modest in the extreme and it is difficult to interpret this as evidence of a political budget cycle.
} 
again took office following elections in November 1982 remaining in office until February 1987 (although Labour withdrew from the coalition shortly before that election).

As set out in table 1, the overall data for the period again indicate that spending in pre and post-election years was greater than in non-election years. However, examination of the year-on-year data shows quite different patterns in different electoral periods (figure 2). ${ }^{25}$ There is clear evidence of a political budget cycle in the 1981-82 period. As can be seen in figure 2, social security budget spending increased very significantly in 1980 and 1981 prior to the June 1981 election. While inflation was running at a high rate at that time, even allowing for inflation the social welfare budget package increased very significantly as it also did in terms of the percentage of gross national product. The coalition budget package in 1982 (which, ironically, failed to achieve parliamentary approval) provided an even more dramatic increase in expenditure even allowing for inflation and changes in GNP. ${ }^{26}$ Of course, we cannot tell how a Fine Gael-Labour government might have behaved in subsequent years. Nonetheless there is clear evidence that the social welfare budget package was used by all the major parties in an attempt to secure political support at a time of instability and repeated elections.

\section{Insert figure 2}

\footnotetext{
${ }^{25}$ The analysis here is based on current year data. However, full year data are available for about half the budgets and are very strongly correlated with the current year data $(0.89)$.

${ }^{26}$ I have categorised this as a pre-election budget. Obviously an election was not intended at this time. However, given that the Fine Gael led government was in a minority position, an election must have been in the minds of those framing the budget. This budget, insofar as these social security aspects went, was substantially enacted by the Fianna Fáil government which took office later that year.
} 
There is no indication of a political budget cycle in the rest of this period. The Fine GaelLabour coalition did provide very significant increases in social security expenditure in mid-1970s dwarfing the sort of increases which had been provided by Fianna Fáil in the previous decade. ${ }^{27}$ However, these increases are almost countercyclical from a political point of view. The largest increases were provided in the years following the 1973 election and increases had reduced significantly by the time of the 1977 election. Subsequently the 1982-86 coalition also provided moderate increases which were again almost counter-cyclical falling in size as the election approached. ${ }^{28}$

$1987-2007$

This period represents the third (and ongoing) period of Fianna Fáil hegemony with Fianna Fáil in office (on its own or with a variety of coalition partners) for all but two and a half years of the period. Again the global figures suggest a political budget cycle effect but mask differing trends in different elections. As set out in table 1 pre-election spending is significantly higher than spending in other years but this effect is entirely driven by the 2002 and 2007 elections. Short-term elections occurred in both 1989 and 1992 but there is no sign of any significant change in social security expenditure in the run-up to these elections (figure 3 and 4). ${ }^{29}$ The Fianna Fáil-Labour coalition, elected in 1992, fell in late 1994 and, for the only time to date, a new 'Rainbow' government-

\footnotetext{
${ }^{27}$ While inflation was very high in the period, reaching 20.9 per cent. in 1975 , this does not account for the significant increase. For example, the nominal size of the budget package increased by almost 500 per cent. from 1972 to 1973 at a time when inflation was 11.4 per cent.

${ }^{28}$ There was, in effect, no pre-election budget on this occasion as the two parties failed to agree a budget and elections were called: (Laver et al., 1987).

${ }^{29}$ The 1992 election, in particular, was unintended resulting from the withdrawal of support by the Progressive Democrat party for the Fianna Fail led government: Gallagher and Laver (1993).
} 
consisting of Fine Gael, Labour and Democratic Left - took office without an election in early 1995. This government remained in office until the elections in 1997 when it was replaced by a Fianna Fáil-Progressive Democrat coalition which remained in office to 2007 - being successfully re-elected in $2002 .{ }^{30}$ For the earlier part of this period there is little indication of a political budget cycle effect. While the increases provided by the Rainbow coalition in the 1997, just before the election, were a significant increase on the previous year, they were less in real terms than the increase provided in the first Rainbow budget.

Insert figure $3 \& 4$

The major exceptions to this are the 2002 and 2007 elections. These are perhaps the clearest examples of a political budget cycle which one could wish to find. Spending in the early years of the 1997-2002 Fianna Fáil-Progressive Democrat government was at about the same level (as a percentage of GDP) as under the previous Rainbow government. However expenditure rose significantly as the 2002 election approached. Immediately after the election the social welfare budget package dropped dramatically. This reduction led to the deferral of the implementation of several commitments such as increases in child benefit. The state of the public finances was put forward as the reason for the dramatic reduction in the additional expenditure on social security in the postelection period. It is, however, perhaps difficult to believe that the somewhat limited difficulties which arose in the public finances in 2003 were so wholly unknown one year

\footnotetext{
${ }^{30}$ Following the recent 2007 elections Fianna Fáil has returned to government in coalition with the Green Party and a much reduced Progressive Democrats.
} 
earlier as to justify the entirely different approach to social security expenditure postelection . Subsequently, following poor election results for the government in the 2004 local EU elections, social security spending increased substanntially again as the 2007 election approached.

The finding of a very clear budget cycle in the 2002 and 2007 elections is obviously not in line with Warin and Donahue's (2006) conclusion that the Treaty of Maastricht and the constraints imposed by the Stability and Growth Pact hindered a political budget cycle effect. ${ }^{31}$ Of course, a general trend as shown in comparative studies is not inconsistent with individual countries showing a contrary tendency and the exceptional state of the Irish economy in the period must be borne in mind.

\section{Conclusion}

In total we find that elections were the occasion for a significant pre-or post increase in the size of the social welfare budget package at 12 elections ${ }^{32}$ out of the 26 elections included in this study. ${ }^{33}$ However, of these, four related to a change in the party in power which was not subsequently followed by the evidence of a political budget cycle. ${ }^{34}$ It seems inappropriate to describe the implementation of different policies as evidence of a

\footnotetext{
${ }^{31}$ Although Mink and de Haan (2005) come to the opposite conclusion.

${ }^{32}$ These were 1932, 1944, 1948, 1951, 1965, 1969, 1973 (both pre-and post-), 1981 (twice), 1982, 2002 and 2007.

${ }^{33}$ The elections of the first four Dails are excluded. The first three elections did not take place under normal circumstances. While a more or less normal politics may have resumed by the 1923 election, there was little opportunity in this election for the development of a political budget cycle.

${ }^{34}$ In 1932, 1948, 1951 and 1973.
} 
political budget cycle. In addition, it is difficult to categorise the 1965 election pattern as a political budget cycle.

Our study does indicate that political budget cycles existed in relation to the Irish social security budget process in relation to eight of the elections studied (about one-third) ${ }^{35}$ The first such occurrence is in 1944 when Fianna Fáil altered its previous approach and put much more emphasis on social policy expenditure (Cousins, 2003, 118-20). A clear but modest political budget cycle can be seen in relation to the two elections in 1969 and 1973 - again under a Fianna Fáil government. The political instability of the early 1980s appears to have given rise to political budget cycle effects in the three elections of 1981 and 1982 under both Fianna Fáil and the Fine Gael-Labour coalition. Finally, the 2002 and 2007 elections provide perhaps the clearest examples of a political budget cycle in the period in question.

From this study we can draw a number of conclusions:

1) Political budget cycles appear to be becoming somewhat more common (albeit not in any consistent manner) with the first political budget cycle not reported until 1944 but with political budget cycles repeated in each decade since the 1960s (except the 1990s) (table 2).

\section{Insert table 2}

\footnotetext{
${ }^{35}$ Recall that an increase in the social security expenditure is apparent twice in the 1973 election: firstly a very modest political budget cycle effect before the election and, subsequently, a much more of a significant but noncyclical increase after the change of government in that election.
} 
2) Political budget cycles appear to be more likely where there is a relatively little policy difference between the parties contesting for election for example in 1944 (Lee, 1989), 2002 (Benoit and Laver, 2006) and 2007, and where the ruling party remains in office in the long-term (for example in 1944, 1969 and 1973, 2002 and 2007). ${ }^{36}$

3) Non-cyclical increases are more likely where there is a change in the party of government for example in 1932-3 and in 1973-5 with the new party wishing to emphasise the difference in its policies. Perhaps surprisingly however none of these parties then significantly increased the social welfare budget package in the run-up to the following election.

4) Political budget cycles were, in all but one case, associated with Fianna Fáil or Fianna Fáil-led governments but given that, since 1927, a non-Fianna Fáil government has never been re-elected to office, relatively little significance can be attached to this finding. ${ }^{37}$ However, political budget cycles are absent on a number of occasions when they might have been expected from Fianna Fáil, in particular 1948.

We might suggest that the reason for these patterns is related to the difficulty which a party, which has been in power for a long period and which has relatively little

\footnotetext{
${ }^{36}$ Benoit and Laver's (2006) study of party positions in 2002 reports less difference between the two main Irish parties than is to be found in most other countries studied - a view confirmed by a national study of voter estimates (Benoit and Laver, 2005) and by Benoit and Laver's (2003) finding of 'little significant difference' between the 'economic' policy positions of the election manifestos of the three main parties. Unfortunately, however, there is no quantitative measure of party policy differences over time.

${ }^{37}$ Whether or not such governments might take this as an indicator that they should adopt a political budget cycle approach to enhance their prospects of re-election and/or speculation as to why they have not done so to date falls outside the scope of this paper.
} 
substantive policy difference from its main rival (and, in recent years, is affected by falling party identification (Marsh, 2006)), has in distinguishing its policies from those of its opposition. One option is perhaps to 'signal' its competence through social and economic measures - such as increased welfare benefits. ${ }^{38}$ However, whether this is a credible long-term option (i.e. credible to the electorate) may be open to question. The other (albeit exceptional) occasion where political budget cycles appear to have occurred was in the political instability of the early 1980 s where parties seem to have been prepared to adopt this approach in a bid to gain political support. In contrast, increases in social spending for ideological reasons are more common in earlier decades (1932, 1948 and 1973) and we do not appear to have seen a non-budget cycle increase in social spending (i.e. one reflecting differing party ideologies) since 1973.

Finally, we must ask whether political budget cycles have succeeded in their apparent objective i.e. securing election for the relevant political party. In fact, of the eight occasions on which we have identified a political budget cycle, the political party responsible for the apparent cycle was elected in four (all involving Fianna Fáil) and not elected in four cases. In the 1944, 1969, 2002 and 2007 elections, when the political budget cycle were significant in size and integrated into Fianna Fáil's overall electoral campaign we see a successful electoral outcome.

While, of course, we do not know to what extent the political budget cycle was causally related to electoral success, this record contrasts with Kraemer's (1997) finding of very

\footnotetext{
${ }^{38}$ Superior competence was, for example, a major issue in the 2002 election campaign (Marsh and Kennedy, 2003) and also in 2007.
} 
limited impact for political budget cycles in a study of political budget cycles in Latin America. Kraemer - while finding significant evidence of such cycles -found that they 'did not significantly increase the success rate of the re-election bid of the incumbent' ( $p$. 28). ${ }^{39}$ If this is the case, one might wonder why a rational government would attempt to produce such a cycle. But, as Kraemer points out it may be 'political suicide' for a government not to expand its pre-election budget as the electorate may interpret this as incompetence. ${ }^{40}$

In conclusion, this paper suggests that political budget cycles can help to explain the recent pattern of social security expenditure increases in Ireland. Of course, one cannot simply generalize from this finding to other European countries which may have entirely different patterns. However, this study does suggest that further research into the impact of political budget cycles in other European countries would be on interest and would help to inform the broader debates in the political science literature about the impact of budget cycles.

\footnotetext{
${ }^{39}$ Conversely, however, and in an EU context, Mulas-Granados (2004) found strong evidence that governments responsible for fiscal adjustments were less likely to be re-elected (although this impact declined in the post-Maastricht period).

${ }^{40}$ It also contrast with Brender and Drazen's (2006) conclusion, based on a survey of 164 elections in 23 developed countries, that increased financial deficits reduce the possibility that a leader is re-elected. However, due to the ongoing economic boom Irish politicians can adopt an expansionary fiscal policy without running deficits.
} 


\section{References}

Akhmedov, A. and E. Zhuravskaya, 2004. 'Opportunistic political cycles: test in a young democracy setting' Quarterly Journal of Economics, 119(4), 1301-38.

Alesina, A., G.D. Cohen and N. Roubini, 1991. Macroeconomic policy and elections in OECD democracies, NBER working paper 3830.

Andrikopoulos, A., I. Loizides and K. Prodromidis, 2004. 'Fiscal policy and political business cycles in the EU' European Journal of Political Economy 20 (1), 125-52. Asutay, M., 2004 .'Searching for opportunistic political business cycles in Turkey', conference paper, European public choice society, Berlin.

Benoit K. and M. Laver, 2003, 'Estimating Irish party policy positions using computer wordscoring: the 2002 Elections' Irish Political Studies, 18(1), 97-107.

Benoit K. and M. Laver, 2005 'Mapping the Irish policy space: voter and party spaces in preferential elections' Economic and Social review 36(2), 83-108.

Benoit K. and M. Laver, 2006, Party policy in modern democracies. London: Routledge. Bew, P. and H. Patterson, 1982. Seán Lemass and the making of Modern Ireland 194566, Dublin: Gill and MacMillan.

Bittencourt, J. L. and R. O. Hilbrecht, 2002. Ciclo politico na economia Brasileria: um teste para a execuão orçamentária dos governos estaduais - 1983/2000, proceedings of the XXXIst. Brazilian Economics Meeting. Brender, A. and A. Drazen, 2004. Political budget cycles in new versus established democracies, NBER working paper 10539. 
Brender, A. and A. Drazen, 2006, "Political Implications of Fiscal Performance in OECD Countries", in Franco, D., ed., Proceedings of the 8th International Public Finance Workshop, Banca d'Italia.

Bristow, J.A. and A.A. Tait, 1968 Economic Policy in Ireland, Dublin: IPA.

Bruhn, K., 1996. 'Social spending and political support: the 'lessons' of the national solidarity program in Mexico,' Comparative Politics, 28 (2) 151-77.

Buti, M. and P. Van De Noord, 2003. Discretionary fiscal policy and elections: the experience of the early years of EMU, OECD economics department working paper 351.

Carty, R. K. (1981) 'Brokerage and Partisanship: Politicians, Parties and Elections in Ireland' Canadian Journal of Political Science / Revue canadienne de science politique, Vol. 14, No. 1 53-81

Cousins, M., 2003. The birth of social welfare in Ireland, 1922-1952, Dublin: Four Courts Press.

Dion, M., 2000. 'The political economy of social spending: the Mexican solidarity programme, 1988-1994' Estudios Sociologicos, 18, 53, 000.

Drazen, Allan, 2001. 'The political business cycle after 25 years' NBER macroeconomics annual 2000, Cambridge : MIT Press.

Ebbinghaus 'How the cases you choose limit the questions you ask' paper presented at the European Consortium of Political Reserarch, Marburg.

Eslava, M., 2005. Political budget cycles or voters as fiscal conservatives? Evidence from Colombia, working paper CEDE 2005-12.

Gallagher, M. and M. Laver, 1993. How Ireland voted 1992, Dublin: Folens. 
Gallagher, M., M. Marsh and P. Mitchell, How Ireland voted 2002. London: Palgrave. Galli, E. and S. Rossi, 2002. 'Political Budget Cycles: The case of the western German lander,' Public Choice 110 (3-4) 283-303.

Gonzales, M. De Los Angeles, 2002. 'Do changes in democracy affect the political budget cycle? Evidence from Mexico’ Review of development economics, 6 (2), 204224.

Hall, P.A. 2003, 'Aligning ontology and methodology in comparative research', in J. Mahoney and D. Rueschemeyer (eds.), Comparative Historical Analysis in the Social Sciences. Cambridge: Cambridge University Press.

Harrison, M. and Michael Marsh, 1998. 'A re-examination of an Irish government popularity function' Public Choice 94, 367-83.

Komito, Lee. (1984) "Irish Clientelism: A Reappraisal.” The Economic and Social Review 15(3):173-194

Kraemer, M., 1997. Electoral Budget Cycles in Latin America and the Caribbean:

Incidence, Causes and Political Futility, Inter American Investment Bank, working paper WP-354.

Kwon, H. Y., 2001. 'The politics of public spending in a 'developmental state': South Korea, 1987-1997' conference paper, Yale University.

Laver, Michael, P. Mair and Richard Sinnott, 1987. How Ireland voted: the Irish general election 1987. Dublin: Poolbeg.

Lee, Joseph, 1985, Ireland 1912-85. Cambridge: Cambridge University Press. 
Magaloni, B., A. Diaz-Cayeros and F. Estevez, 2003. The erosion of party hegemony, clientelism and portfolio diversification: The Programma Nacional de Solidaridad (Pronasol) in Mexico, working paper, Stanford University.

Marsh, M. 2006, 'Anchoring a floating party system: party identification in Ireland,' Electoral Studies, 25(3) 489-508.

Marsh. Michael and F. Kennedy, 2003 'Taking the credit and avoiding the blame: parties and voting behaviour in Ireland 2002'. Paper presented at ECPR, Marburg, September. Medina, L. and D. Lema 2003. 'Ciclos presupuestarios de origin electoral: El caso de las provinces argentines' procedings of the XXXVIIIth. annual meeting of the AAER. Mink, Mark and Jakob De Haan, 2005. Has the stability and growth pact impeded political budget cycles in the European Union? CESifo working paper 1532.

Mulas-Granados, C., 2004. 'Voting against spending cuts: the electoral costs of fiscal adjustments in Europe' European Union Politics 5(4) 467-93.

O'Malley, Eoin and Matthew Kerby (2004) 'Chronicle of a death foretold? understanding the decline of fine gael' Irish Political Studies, Volume 19, Issue 1 , pages $39-58$

Persson, T. and G. Tabellini, 1990. Macroeconomic Policy, Credibility and Politics, Chur: Harwood Academic Publishers.

Persson, T. and G. Tabellini, 2002. Do electoral cycles differ across political systems?, IGIER working paper, Bocconi University.

Puente, J. M. (2004) La economía political del gasto social en Venezuela' revista del $B C V$, XVIII, 1. 
Remmer, K. L., 1993. 'The political economy of elections at Latin America, 1980-1991' American Political Science Review, 87 (000) 393-407.

Schady, N. R., 2000. 'The political economy of expenditures by the Peruvian social fund (FONCODES), 1991-95' American Political Science Review, 94, 289-304.

Shalev, M. 'Limits of and Alternatives to Multiple Regression in Macro-Comparative Research' Conference Paper, 2002.

Shi, M. and J. Svensson, 2002a. Conditional Budget Cycles, CEPR discussion paper 3352.

Shi, M. and J. Svensson, 2002b. Political budget cycles in developed and developing countries, IIES working paper, Stockholm University.

Shi, M. and J. Svensson, 2003. 'Political budget cycles: a review of recent developments,' Nordic Journal of Political Economy, 29(1), 67-76.

Tujula, M. and G. Wolswijk, 2004. What determines fiscal balances? An empirical investigation in determinants of changes in OECD budget balances, ECB working paper 422.

Tutar, I. and A. Tansel, 2000. Political Business Cycles, Institutional Structure and Budget Deficits in Turkey, Economic research forum working paper 2019, Middle East Technical University.

Van Dalen, H. P. and O. H. Swank, 1995. Government spending cycles: ideological or opportunistic? Erasmus University Rotterdam, research memorandum 9507. Von Hagen, J., 2003. Fiscal discipline and growth in Euroland: experiences with the stability and growth pact, ZEI working paper B06-2003. 
Warin, T. and K. Donahue The Stability and Growth Pact: a European answer to the political budget cycle? Middlebury College Economics Discussion Paper No. 06-06. Yarahuan, G. Pérez, 2003 'Social programs and electoral competition: the political economy of the Mexican National Fund for Social Enterprises (1992-200)' conference paper, Dallas. 
Table 1: Budget sizes (current year) in pre, post and non-election years, 1960-2007 (\% of GDP)

$\begin{array}{llll} & \text { Pre } & \text { Post } & \text { Non } \\ 1960-1972 & 0.26 & 0.26 & 0.14 \\ 1973-1986 & 1.24 & 0.88 & 0.68 \\ 1987-2007 & 0.51 & 0.26 & 0.42 \\ & & & \\ \text { Average } & 0.67 & 0.47 & 0.41\end{array}$

Table 2: Political budget cycles and elections by decade, 1923-2007

Elections Political budget cycles

$\begin{array}{lll}1920 \mathrm{~s} & 2 & 0 \\ 1930 \mathrm{~s} & 4 & 0 \\ 1940 \mathrm{~s} & 3 & 1 \\ 1950 \mathrm{~s} & 3 & 0 \\ 1960 \mathrm{~s} & 3 & 1 \\ 1970 \mathrm{~s} & 2 & 1 \\ 1980 \mathrm{~s} & 5 & 3 \\ 1990 \mathrm{~s} & 2 & 0 \\ 2000 \mathrm{~s} & 2 & 2 \\ & & \\ \text { Total } & 26 & 8\end{array}$




\section{Appendix 1: Details of social security budgetary increases, 1924-2007}

\begin{tabular}{|c|c|c|c|c|c|c|}
\hline \multirow[t]{2}{*}{ Budget date } & \multirow{2}{*}{$\begin{array}{l}\text { Source } \\
\text { Dáil } \\
\text { Debates } \\
\text { (vol., col.) } \\
\end{array}$} & \multicolumn{2}{|c|}{$\begin{array}{l}\text { SW Budget Increase } \\
£ \text { to } 1992 / € 1993-2007\end{array}$} & \multicolumn{2}{|c|}{$\begin{array}{l}\% \text { of national } \\
\text { income }\end{array}$} & \multirow[t]{2}{*}{ Election date } \\
\hline & & $\begin{array}{l}\text { Current } \\
\text { Year }\end{array}$ & Full Year & $\begin{array}{l}\text { Current } \\
\text { Year }\end{array}$ & $\begin{array}{l}\text { Full } \\
\text { Year }\end{array}$ & \\
\hline & & & & & & 27 August 1923 \\
\hline 25 April 1924 & 7,11 & 0 & 0 & & & \\
\hline 22 April 1925 & 11,9 & 0 & 0 & & & \\
\hline 21 April 1926 & 15.135 & 0 & 0 & & & \\
\hline \multirow[t]{3}{*}{21 April 1927} & 19,1337 & 0 & 0 & & & \\
\hline & & & & & & 09 June 1927 \\
\hline & & & & & & 15 September 1927 \\
\hline 25 April 1928 & 23,344 & 0.175 & & 0.109 & & \\
\hline 24 April 1929 & 29,752 & 0 & 0 & & & \\
\hline 30 April 1930 & 34,1063 & 0 & 0 & & & \\
\hline \multirow[t]{2}{*}{06 May 1931} & 38,753 & 0 & 0 & & & \\
\hline & & & & & & $\begin{array}{l}16 \text { February } 1932- \\
\text { change of government }\end{array}$ \\
\hline \multirow[t]{2}{*}{11 May 1932} & 41,1489 & 0.35 & 0.58 & 0.241 & 0.399 & \\
\hline & & & & & & 24 January 1933 \\
\hline 10 May 1933 & 47,734 & 0.45 & & 0.321 & & \\
\hline 09 May 1934 & 52,615 & 1.45 & & 1.008 & & \\
\hline 15 May 1935 & \multicolumn{2}{|l|}{56,851} & 0.25 & & 0.168 & \\
\hline 12 May 1936 & 62,8 & 0 & 0 & & & \\
\hline \multirow[t]{2}{*}{14 April 1937} & 66,735 & 0.2 & & 0.001 & & \\
\hline & & & & & & 01 July 1937 \\
\hline \multirow[t]{2}{*}{12 May 1938} & 71,875 & 0 & 0 & & & \\
\hline & & & & & & 17 June 1938 \\
\hline 10 May 1939 & 75,1972 & 0 & 0 & & & \\
\hline 08 November 1939 & 77,957 & 0 & 0 & & & \\
\hline 08 May 1940 & 80,13 & 0 & 0 & & & \\
\hline 07 May 1941 & 83,21 & & 0.816 & 0.418 & & \\
\hline 06 May 1942 & 86,1613 & 0 & 0 & & & \\
\hline \multirow[t]{2}{*}{05 May 1943} & 89,2265 & 0 & 0 & & & \\
\hline & & & & & & 23 June 1943 \\
\hline \multirow[t]{2}{*}{03 May 1944} & 93,2117 & 1.5 & 2.25 & 0.591 & 0.887 & \\
\hline & & & & & & 30 May 1944 \\
\hline 02 May 1945 & 97,17 & 0 & 0 & & & \\
\hline 08 May 1946 & 100,2349 & 0 & $\overline{0}$ & & & \\
\hline 07 May 1947 & 105,2240 & 0 & 0 & & & \\
\hline \multirow[t]{2}{*}{15 October 1947} & 108,393 & 0 & 0 & & & \\
\hline & & & & & & $\begin{array}{l}04 \text { February } 1948- \\
\text { change of government }\end{array}$ \\
\hline 04 May 1948 & 110,1037 & 0.6 & & 0.188 & & \\
\hline 04 May 1949 & 115,468 & 0 & 0 & & & \\
\hline 03 May 1950 & 120,1617 & 0 & 0 & & & \\
\hline
\end{tabular}




\begin{tabular}{|c|c|c|c|c|c|c|}
\hline 02 May 1951 & 125,1875 & 1.5 & & & & \\
\hline & & & & & & $\begin{array}{l}30 \text { May } 1951 \text { - change } \\
\text { of government }\end{array}$ \\
\hline 02 April 1952 & 130,1113 & 3 & & & & \\
\hline 06 May 1953 & 138,1176 & 0 & 0 & & & \\
\hline \multirow[t]{2}{*}{21 April 1954} & 145,537 & 0 & 0 & & & \\
\hline & & & & & & $\begin{array}{l}18 \text { May } 1954 \text { - change } \\
\text { of government }\end{array}$ \\
\hline 04 May 1955 & 150,678 & 0.9 & 1.25 & 0.20 & 0.27 & \\
\hline \multirow{2}{*}{08 May 1956} & 157,19 & 0.3 & & 0.07 & & \\
\hline & & & & & & $\begin{array}{l}05 \text { March } 1957 \\
\text { change of government }\end{array}$ \\
\hline 08 May 1957 & 161,933 & 0 & 0 & & & \\
\hline 23 April 1958 & 167,599 & 0.883 & & 0.18 & & \\
\hline 15 April 1959 & $\begin{array}{l}\text { Budget } \\
\text { booklet }\end{array}$ & 0 & 0 & & & \\
\hline 27 April 1960 & & 0.61 & & 0.10 & & \\
\hline \multirow[t]{2}{*}{19 April 1961} & & 0.60 & & 0.09 & & \\
\hline & & & & & & 09 October 1961 \\
\hline 10 April 1962 & & 1.075 & & 0.15 & & \\
\hline 23 April 1963 & & 0.6 & & 0.08 & & \\
\hline \multirow[t]{2}{*}{14 April 1964} & & 0.73 & & 0.08 & & \\
\hline & & & & & & 07 April 1965 \\
\hline 11 May 1965 & & 3.22 & 5.7 & 0.33 & 0.59 & \\
\hline 09 March 1966 & & 0.25 & & 0.02 & & \\
\hline 11 April 1967 & & 2.12 & & 0.19 & & \\
\hline 23 April 1968 & & 3.12 & 5.52 & 0.25 & 0.44 & \\
\hline \multirow[t]{2}{*}{07 May 1969} & & 7.41 & & 0.51 & & \\
\hline & & & & & & 18 June 1969 \\
\hline 22 April 1970 & & 5.4 & 8.8 & 0.30 & 0.50 & \\
\hline 28 April 1971 & & 3.75 & & 0.19 & & \\
\hline \multirow[t]{2}{*}{ 19 April 1972} & & 8.3 & 11.6 & 0.34 & 0.47 & \\
\hline & & & & & & $\begin{array}{c}28 \text { April } 1973- \\
\text { change of government }\end{array}$ \\
\hline 16 May 1973 & & 51 & 68.7 & 1.74 & 2.34 & \\
\hline 03 April 1974 & & 37.62 & 50.14 & 1.15 & 1.53 & \\
\hline 15 January 1975 & & 51.25 & 80.76 & 1.25 & 1.97 & \\
\hline 26 June 1975 & & 0 & 0 & & & \\
\hline 28 January 1976 & & 25.5 & & 0.51 & & \\
\hline \multirow[t]{2}{*}{ 26 January 1977} & & 44.5 & & 0.74 & & \\
\hline & & & & & & $\begin{array}{r}16 \text { June } 1977 \text { - change } \\
\text { of government }\end{array}$ \\
\hline 01 February 1978 & & 21.7 & 33.2 & 0.31 & 0.47 & \\
\hline 07 February 1979 & & 39 & 50.4 & 0.47 & 0.61 & \\
\hline 27 February 1980 & & 95 & 126.4 & 0.96 & 1.28 & \\
\hline \multirow[t]{2}{*}{28 January 1981} & & 144 & & 1.21 & & \\
\hline & & & & & & $\begin{array}{r}11 \text { June } 1981 \text { - change } \\
\text { of government }\end{array}$ \\
\hline 21 July 1981 & & 10.2 & 39 & 0.09 & 0.33 & \\
\hline
\end{tabular}




\begin{tabular}{|c|c|c|c|c|c|}
\hline 27 January 1982 & 238.8 & & 1.77 & & \\
\hline & & & & & $\begin{array}{l}18 \text { February } 1982 \\
\text { change of government }\end{array}$ \\
\hline \multirow[t]{2}{*}{25 March 1982} & 0.2 & & 0 & & \\
\hline & & & & & $\begin{array}{l}24 \text { November } 1982- \\
\text { change of government }\end{array}$ \\
\hline 09 February 1983 & 88.6 & & 0.59 & & \\
\hline 25 January 1984 & 70.3 & 152 & 0.42 & 0.92 & \\
\hline 30 January 1985 & 55.4 & 123 & 0.30 & 0.67 & \\
\hline \multirow[t]{3}{*}{ 29 January 1986} & 70.8 & & 0.36 & & \\
\hline & & & & & \\
\hline & 60 & & 0.28 & & $\begin{array}{c}17 \text { February } 1987- \\
\text { change of governmen }\end{array}$ \\
\hline 31 March 1987 & 0 & & 0.00 & & \\
\hline 27 January 1988 & 64.8 & 101 & 0.29 & 0.44 & \\
\hline \multirow{2}{*}{25 January 1989} & 57.5 & 135 & 0.23 & 0.53 & \\
\hline & & & & & 15 June 1989 \\
\hline 31 January 1990 & 78.6 & & 0.28 & & \\
\hline 30 January 1991 & 62 & & 0.21 & & \\
\hline \multirow[t]{2}{*}{29 January 1992} & 85 & 162 & 0.27 & 0.51 & \\
\hline & & & & & 25 November 1992 \\
\hline 24 February 1993 & 95.90 & 229.49 & 0.22 & 0.53 & \\
\hline 26 January 1994 & 91.42 & 199.48 & 0.20 & 0.43 & \\
\hline 8 February 1995 & 114.53 & 269.31 & 0.22 & 0.51 & $\begin{array}{l}\text { Change of government } \\
\text { (without election) }\end{array}$ \\
\hline 23 January 1996 & 101.59 & 204.55 & 0.18 & 0.35 & \\
\hline \multirow[t]{2}{*}{ 22 January 1997} & 144.53 & 272.60 & 0.22 & 0.41 & \\
\hline & & & & & $\begin{array}{r}\text { 06 June } 1997 \text { - change } \\
\text { of governmen }\end{array}$ \\
\hline 2 December 1997 & 158.68 & 285.69 & 0.21 & 0.37 & \\
\hline 2 December 1998 & 243.79 & 401.87 & 0.27 & 0.45 & \\
\hline 1 December 1999 & 320.00 & 544.00 & 0.31 & 0.53 & \\
\hline 6 December 2000 & 744.85 & $1,079.28$ & 0.65 & 0.94 & \\
\hline \multirow[t]{2}{*}{5 December 2001} & 968.30 & $1,079.28$ & 0.78 & 0.84 & \\
\hline & & & & & 17 May 2002 \\
\hline 4 December 2002 & 500.68 & 530.00 & 0.37 & 0.39 & \\
\hline 3 December 2003 & 607.90 & 630.00 & 0.41 & 0.42 & \\
\hline 1 December 2004 & 834.15 & 874.00 & 0.61 & 0.64 & \\
\hline 6 December 2005 & 1065.00 & 1120.00 & 0.73 & 0.77 & \\
\hline 7 December 2006 & 1322.00 & 1467.00 & 0.88 & 0.98 & 24 May 2007 \\
\hline
\end{tabular}

The table above sets out the principal data relied on in this analysis. Column 1 sets out the date of each Budget while column 2 provides the reference to the parliamentary debates setting out the details of the Budget. Since 1959 full details of the Budget are published in an annual Budget booklet. Columns 3 and 4set out the current and full year amounts of the social welfare budget packages in current values ( $£$ to 18992 and $\mathrm{E}$ thereafter). As will be seen, only the current year amount is given in many of the earlier years although now - as the Budget year and calendar year are aligned - the full year 
value is more emphasised. Column 5 and 6 express this amount as a percentage of national income. For the period from 1970 a consistent series of estimates are available from the Central Statistics Office (www.cso.ie). As a significant divergence has developed between gross domestic product (GDP) and gross national product (GNP) since the 1980s and as the later is usually considered a more reliable indicator of national income, I have used the GNP figures for the period from 1970 to 2007 (the GNP data for 2006 and 2007 are estimates). For the earlier period I have used the gross domestic product published by the CSO since 1949 and earlier once-off estimates of national income (see Bristow and Tait, 1968). In general the national income figures are those for the year in which the Budget was announced. However, since December 1997, the annual Budget is announced in December of the previous year (so Budget 2007 was announced in December 2006) and I have used the GNP figures accordingly (i.e. the budget increase announced in December 2006 is shown as a \% of 2007 GNP). Finally, Column 7 sets out the dates of each election and notes changes in government.

I have expressed the social welfare budget package as a percentage of national income as the most reliable way of showing the scale of budget increases over time. An alternative would be to express the social welfare budget package as a \% of government spending or of total social security expenditure (in view of shifts in the ratio of government spending to GNP over the period). However, this would not appear to affect the findings as there is no substantial variation between the social welfare budget package expressed as a $\%$ of GNP and as expressed as a \% of total social security expenditure (at least for the more recent period for which consistent data is available). For example for the period from $198 \mathrm{X}$ to 2007 , although there was a substantial variation in social security spending as a $\%$ of GNP over that period, the correlation between the social welfare budget package expressed as a $\%$ of GNP and as a $\%$ of total spending is $0.9 \mathrm{X}$. Accordingly I have not included this alternative form of analysis in the main paper. A further alternative would be to express the social welfare budget package deflated by the cost-of-living. Again, I tested this approach - particularly in periods of high inflation - but it did not affect the findings reported here. 
Figure 1: Social welfare budgets as \% of GDP/GNP, 1960-72 (current year)

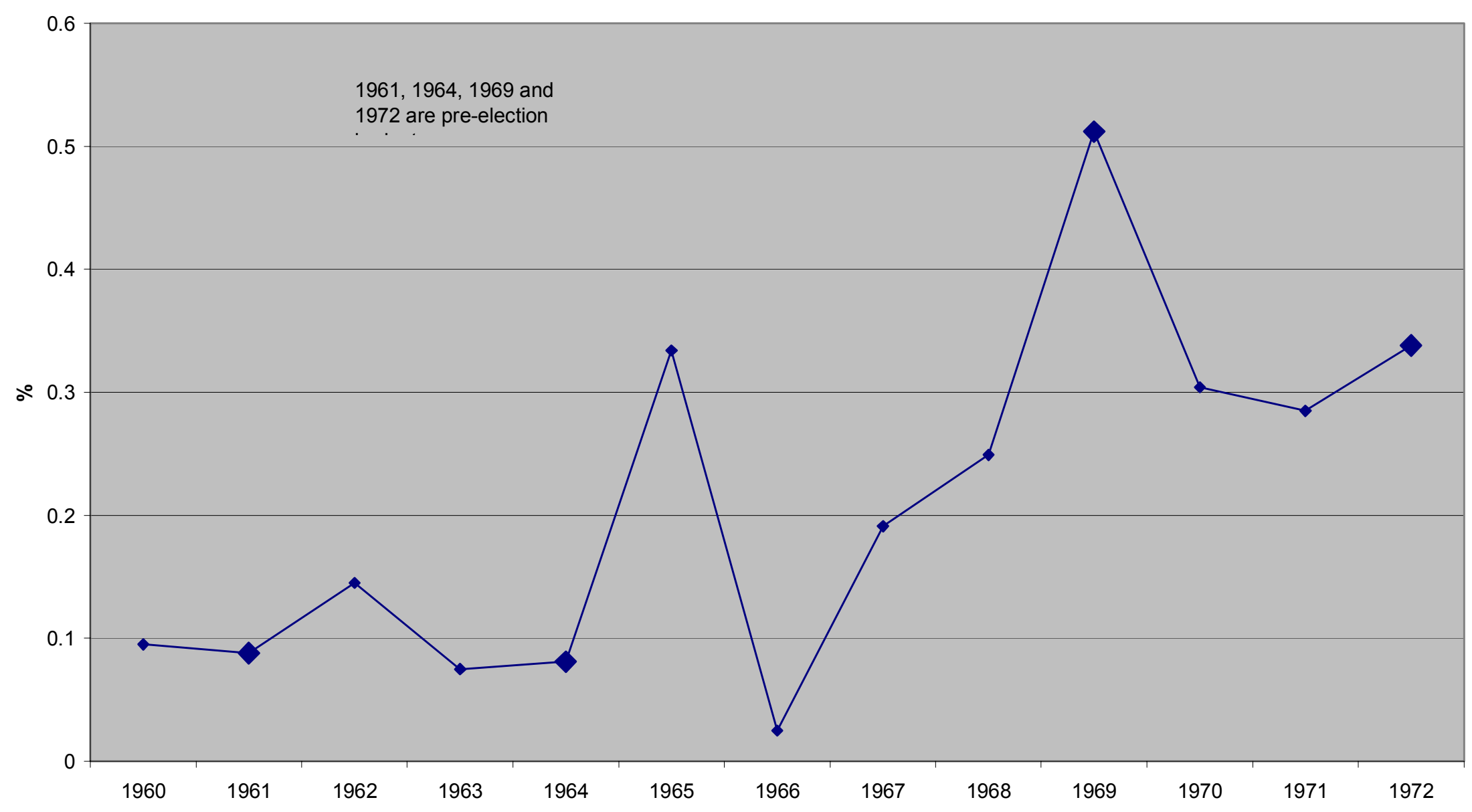


Figure 2: Social welfare budgets as \% of GNP, 1973-86 (current year)

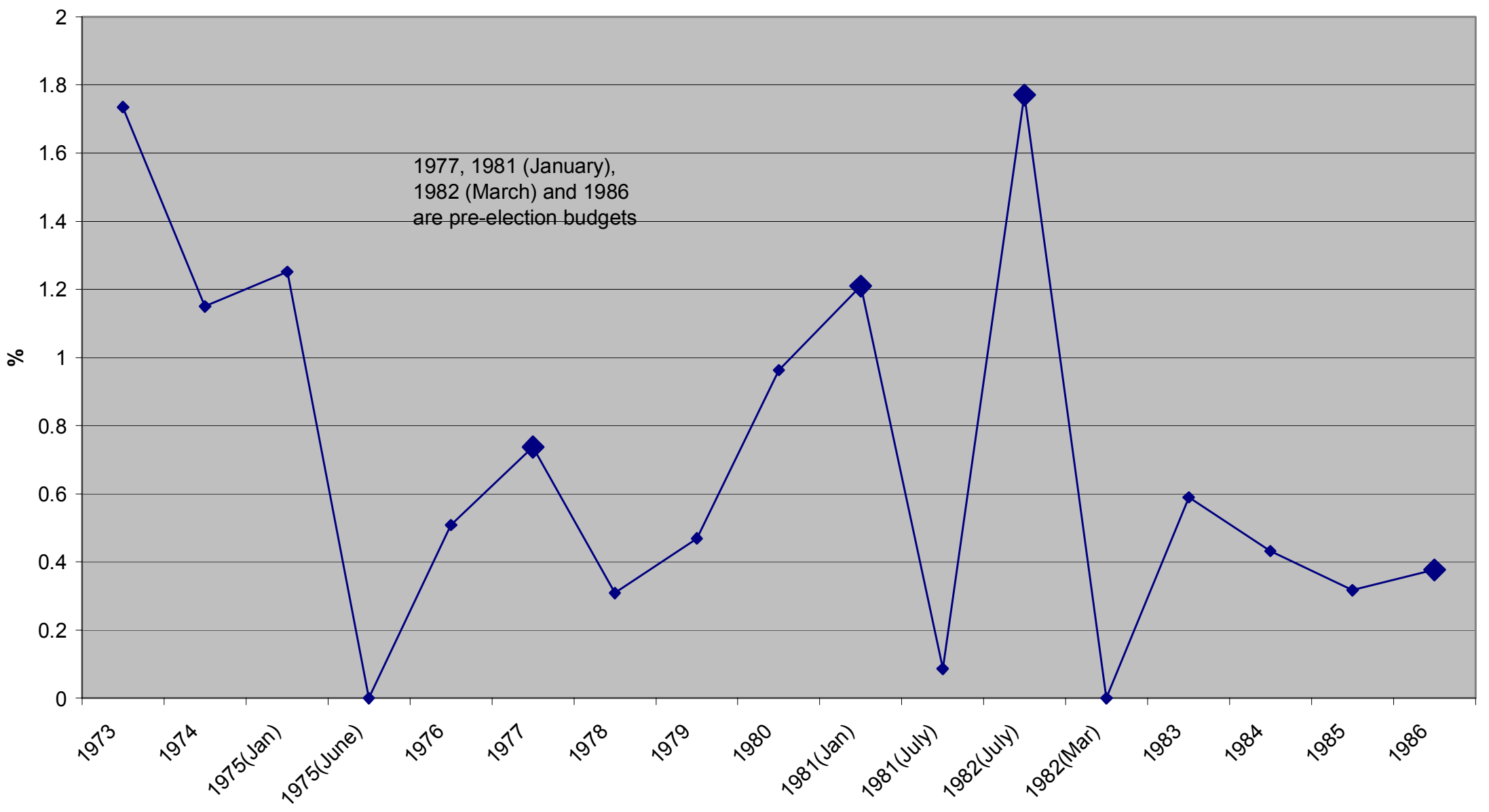


Figure 3: Social welfare budgets as \% of GNP, 1987-2007 (current year)

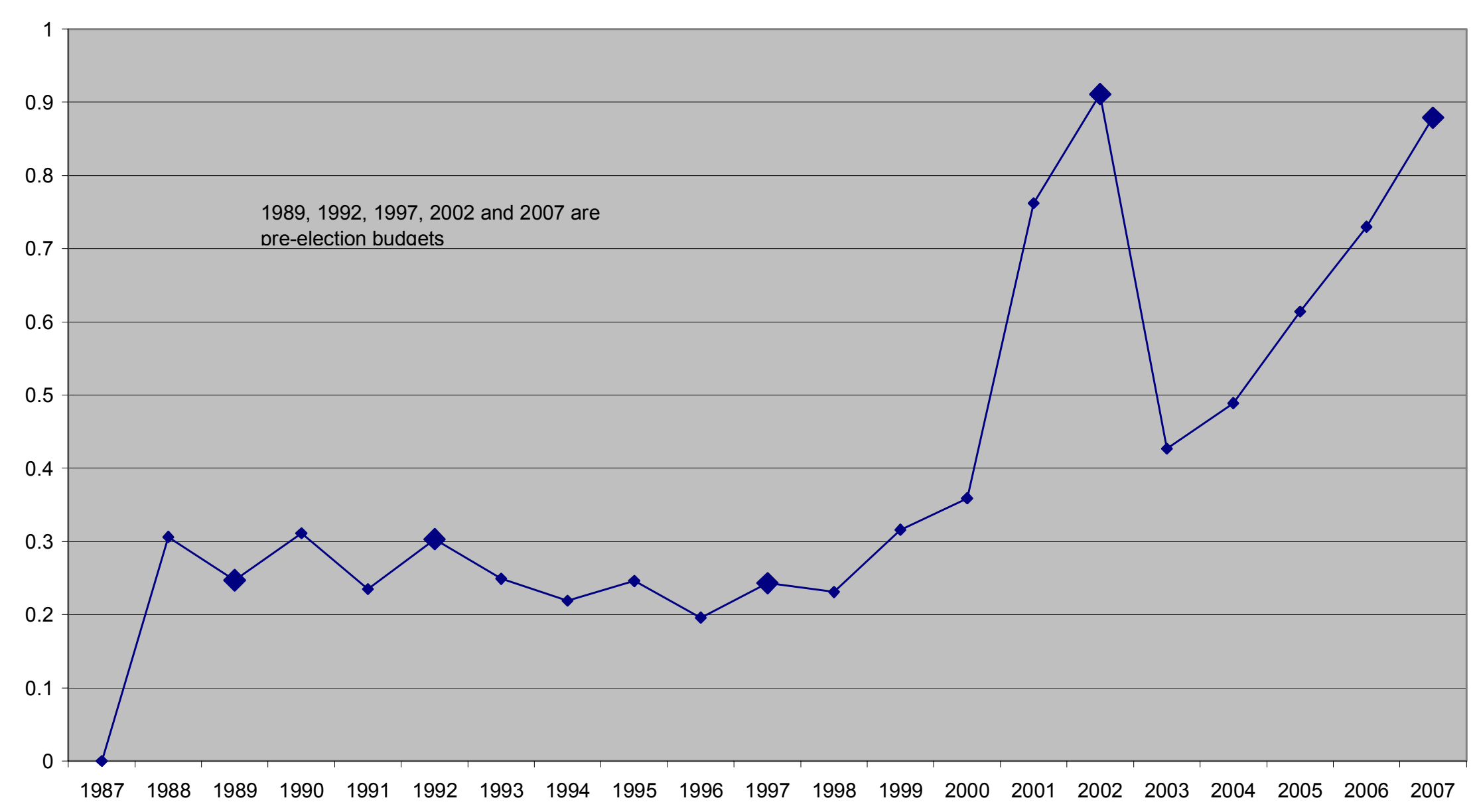


Figure 4: Social welfare budgets as \% of GNP, 1991-2007 (full year)

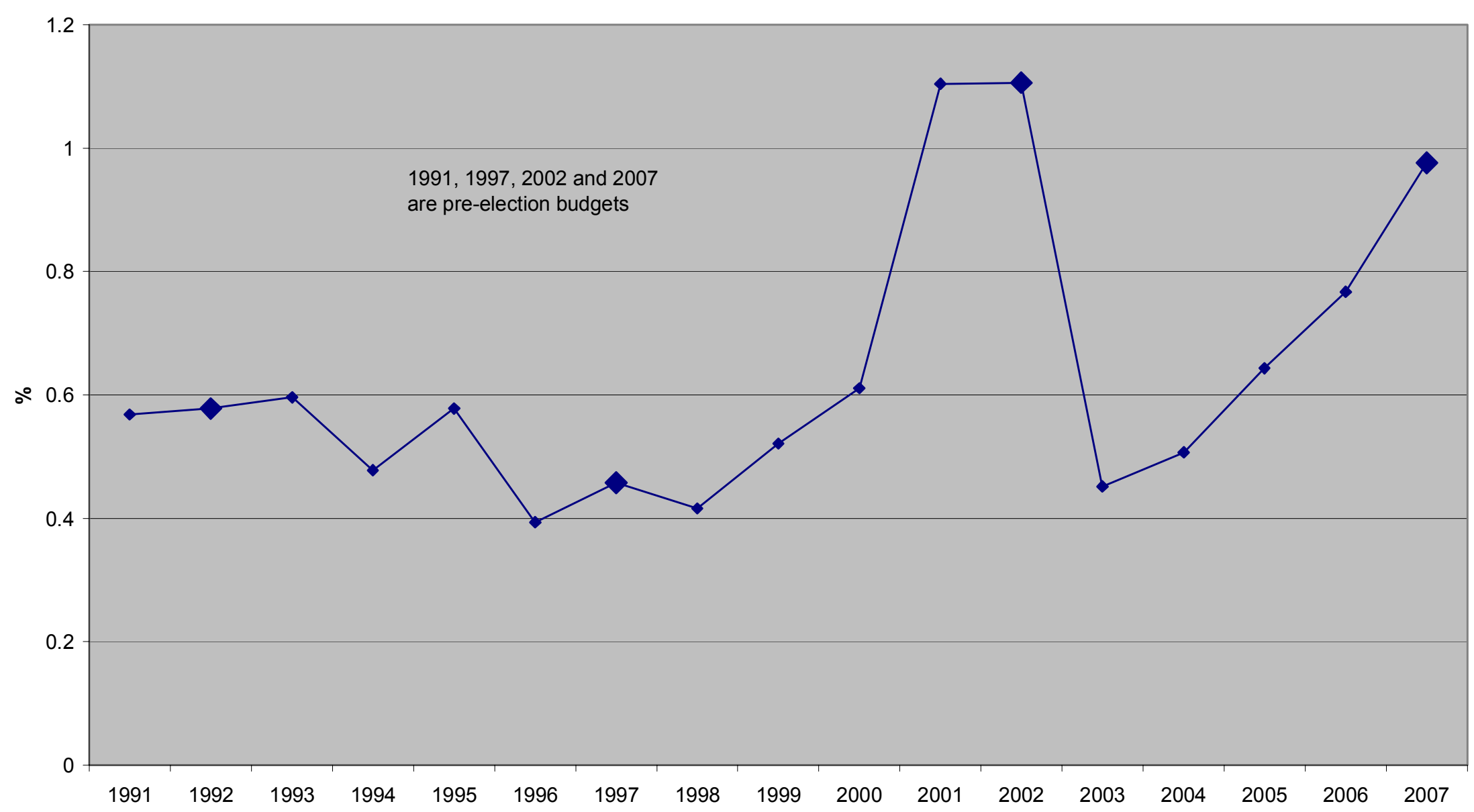

